\title{
The Future of Hydrocarbon Development in Greenland: Perspectives from Residents of the North Slope of Alaska
}

\author{
Anne Merrild Hansen ${ }^{1}$ and Ross A. Virginia ${ }^{2}$ \\ (Received 1 November 2017; accepted in revised form 11 June 2018)
}

\begin{abstract}
Although Greenland has pursued hydrocarbon development over the last four decades, no viable reserves have been found to date. Therefore, local Greenland communities have little experience or knowledge of how such development might affect their way of life or how to influence project development and outcomes should a significant reserve be found. On the North Slope of Alaska, in contrast, hydrocarbon extraction was commercialized in the 1970s, and the industry is now highly developed. North Slope residents have experienced dramatic influences on their everyday lives and well-being as a result of large-scale hydrocarbon projects. Some consequences have been welcomed, such as economic development and higher employment rates; however, other impacts are harmful, such as reduced ability of local peoples to maintain subsistence hunting practices. The villages on Alaska's North Slope share many features in common with settlements in Greenland, such as small size, isolation, and limited political influence. In this study, we explore how Greenlanders might learn from the Alaska experience by examining the comments of North Slope residents. We propose that increased local-to-local recommendationsharing across the Arctic would better guide sustainable development practices and benefits into potential future projects in Greenland. We conclude that an Arctic "Community Guide" and the process to create one could improve planning and implementation of hydrocarbon projects across the Arctic and promote locally appropriate sustainable development in the affected communities.
\end{abstract}

Key words: hydrocarbon; oil and gas; sustainable development; Arctic; FPIC; public participation; community guide

RÉSUMÉ. Bien que le Groenland se soit adonné à l'exploration d'hydrocarbures ces quatre dernières décennies, aucune réserve rentable n'a été trouvée à ce jour. Par conséquent, les communautés du Groenland possèdent peu d'expérience ou de connaissances pour savoir comment des travaux de mise en valeur pourraient modifier leur mode de vie ou comment elles pourraient influencer le développement et les résultats d'un projet en cas de découverte de réserves importantes. En revanche, sur le North Slope de l'Alaska, l'extraction d'hydrocarbures a été commercialisée dans les années 1970, si bien que cette industrie y est maintenant fortement développée. La vie de tous les jours et le bien-être des résidents du North Slope ont connu des influences dramatiques en raison d'importants projets de mise en valeur d'hydrocarbures. Certaines incidences ont été bien accueillies, comme le développement économique et la hausse des taux d'emploi, mais d'autres ont été nuisibles, comme la diminution des occasions de pratiquer la chasse de subsistance dans la région. Les villages du North Slope de l'Alaska ont de nombreuses caractéristiques en commun avec ceux du Groenland, comme leur petite taille, leur isolement et leur influence politique restreinte. Dans cette étude, nous explorons la façon dont les Groenlandais pourraient tirer profit de l'expérience de l'Alaska en dépouillant les commentaires des gens du North Slope. Nous proposons que le partage accru de recommandations locales à l'échelle de l'Arctique permettrait de mieux orienter les pratiques de développement durable et leurs retombées dans le cadre de projets susceptibles de se concrétiser plus tard au Groenland. Nous concluons en affirmant qu'un « guide communautaire » de l'Arctique et le processus de création d'un tel guide pourraient améliorer la planification et la mise en œuvre de projets d'hydrocarbures dans l'Arctique, en plus de favoriser un développement durable local adéquat dans les localités concernées.

Mots clés : hydrocarbures; pétrole et gaz; développement durable; Arctique; consentement préalable donné librement et en connaissance de cause; participation du public; guide communautaire

Traduit pour la revue Arctic par Nicole Giguère.

\footnotetext{
${ }^{1}$ Professor of Social Science, Arctic Oil and Gas Centre, Ilisimatusarfik, Greenland, and Head of AAU Arctic, Aalborg University, 9000 Aalborg, Denmark; merrild@plan.aau.dk

${ }^{2}$ Myers Family Professor of Environmental Science, Environmental Studies Program and Director, Institute of Arctic Studies, Dartmouth College, Hanover, New Hampshire 03755, USA

(C) The Arctic Institute of North America
} 


\section{INTRODUCTION}

The idea that hydrocarbon extraction and energy production lead to economic growth has been widely held, and the understanding of these activities as an economic stimulant is generally supported (Smith et al., 2001; Anderson and Theodori, 2009; Park and Sokowsky, 2009). However, many studies have found that the local social and economic costs of development tend to be greater, and the benefits fewer, than expected (Park and Sokowsky, 2009). In addition, initiatives taken to secure sustainable development goals in communities exposed to the impacts of hydrocarbon development have not always been sufficient to overcome the negative outcomes of these projects (Pearce, 1994; Stedman et al., 2012; Hansen et al., 2016b).

Currently, pressing questions remain about future industrial oil and gas development in Greenland. Despite many international efforts to reduce the world's dependence on hydrocarbon-based energy and to combat climate change, demand for oil and gas remains high. In addition, increasing sea ice melt and better accessibility to the Arctic regions make exploration and future extractive industry development in this part of the world more attractive. Therefore, it seems likely that some Greenland communities will face the complex challenges arising from extractive industry development in the near future. To prepare for these challenges, an assessment of best practices and the experiences of other Arctic communities could help to ensure a sustainable and environmentally sound path towards future hydrocarbon development in Greenland.

As a first step towards community-targeted guidelines, we gathered the perspectives of governmental officials, researchers, and local residents in the areas already affected by development on the North Slope of Alaska. Using these findings, we considered how a community guide could be created and point to relevant research and practical activities that could lead to recommendations on how Greenland and other Arctic communities might prepare for large-scale industries.

\section{History of Hydrocarbon Development in Greenland}

Hydrocarbon exploration in Greenland has been taking place at varying intensity since the 1970s without any commercial discoveries (AMAP, 2007; Hansen and Tejsner, 2016). After a period of generally low activity, the beginning of the new millennium brought remarkable increases in the global market price of crude oil and the interest of oil companies in exploration (Hansen and Tejsner, 2016). The Government of Greenland (Naalakkersuisut) consequently issued licenses to open several areas in West Greenland for exploration in 2002, 2003, and 2004 (Wilson et al., 2017). After the United States Geological Survey (USGS) in 2008 published assessments of large quantities of undiscovered oil and gas resources in the Arctic (Robertson et al., 2008), Naalakkersuisut released a second hydrocarbon strategy in 2009. This updated strategy ultimately led to the issue of 11 new exploration licenses: seven in NW Greenland in 2010 and four in NE Greenland in 2012 and 2013 (Wilson et al., 2017). In 2010 and 2011, Cairn Energy PLC drilled eight test wells off the shore of central West Greenland. However, all these wells were found to be commercially dry (Wilson et al., 2017).

In 2012 a consortium of oil companies with exploration licenses in NW Greenland drilled 11 shallow core holes to evaluate prospectivity in the area (Hansen et al., 2015). An additional four operating companies (Maersk Oil Kalaallit Nunaat, ConocoPhillips, Cairn Energy PLC, and Shell Greenland) held licenses to a total number of five exploration blocks in the Baffin Bay area in NW Greenland where extensive seismic exploration and site surveys were undertaken in 2012 and 2013 (Hansen et al., 2015). This combined effort to locate viable hydrocarbon reserves was the most extensive in a single area of Greenland to date (Hansen and Tejsner, 2016). The exploration was expected to lead to production of oil and related industrial activities such as establishment of ports, roads, staff housing, and pipelines, as well as supply chain services, such as catering, transportation, and fuel supply. Such rapid growth in industry would most likely produce significant impacts on the economy, the natural environment, and the quality of everyday life in local communities.

In 2014, Naalakkersuisut again presented a new strategy for hydrocarbon development, as well as mineral extraction. This strategy specified selected areas to be announced for "open-door" licensing off the shore of West Greenland and onshore at Jameson Land on the east coast (Government of Greenland, 2014). It also allowed for new licensing rounds off Disko and West Nuussuaq. In 2015, however, when the global market price of oil dropped sharply from $\$ 115$ per barrel to less than $\$ 40$ (World Economic Forum, 2016), the level of interest in hydrocarbon exploration in Greenland similarly declined. In 2016, only a very limited amount of exploration activity took place, and in 2017 all activity ceased.

Impact Assessment as a Tool to Promote Sustainable Development

The main tools for managing the impacts of new projects and securing local influence on project development in Greenland are Social Impact Assessment (SIA) and Environmental Impact Assessment (EIA) (Noble and Udofia, 2015; Vanclay et al., 2015). Under current law, companies are required to complete both assessments as part of the application process for exploration, drilling, and production (Naalakkersuisut, 2018). For both SIA and EIA, the Greenland government has issued guidance on how a company should conduct the required investigations (Hansen et al., 2016a). The guidelines emphasize cooperation between the company and the affected local community to provide public participation and input on the project's development (Naalakkersuisut, 2016). 
The purpose of impact assessment tools such as SIA and EIA is to ensure informed decision making by mainstreaming environmental and social considerations and to assess and mitigate the potential negative impacts of a development and enhance its benefits in cooperation with local communities (Vanclay et al., 2015). Local guidelines from the international literature and impact assessment practitioners generally agree that the overall purpose of these tools is to promote sustainable development by providing local communities an avenue to influence the design of and decisions about development initiatives (Senécal et al., 1999; João et al., 2011).

Impact assessment is typically based on a common procedure, but adapted to the specific decision-making process. Impact assessment involves four steps: screening, scoping, assessment (including considering alternatives and proposing mitigation measures), and reporting (Wood, 2003; Morgan, 2012). Public participation is an integral part of impact assessment (Glasson et al., 2013; Hansen and Larsen, 2016). It is integrated in different phases of the process. Some Arctic jurisdictions, such as Norway, Greenland, Canada, and Alaska, include public participation in relation to the scoping phase, and most jurisdictions provide an opportunity for public review and comment on the published impact statement and in subsequent decision making (Hansen and Larsen, 2016). Public participation in the Arctic includes accessing local knowledge, which includes traditional and Indigenous knowledge; understanding how local communities might respond or adapt to changes; and encouraging connections between companies and local residents (Olsen and Hansen, 2014). However, Hansen et al. (2015) reported that in Greenland, local residents had surprisingly little interest in participating in arranged public meetings as part of the public consultation process. The companies and government officials involved in this case concluded that the public suffered from consultation fatigue. Interviews and conversations with communities in NW Greenland in 2013 revealed that this lack of engagement resulted from the interviewees' limited understanding of what the EIA processes involved and how they could influence the outcomes (Hansen and Tejsner, 2016).

\section{Critique of Public Participation Processes in Greenland}

According to prior investigations in Greenland, Olsen and Hansen (2014) argue that, to date, local participation in research and the impact assessment processes for hydrocarbon projects have not been engaging and have not adequately prepared the community for future development impacts. Denmark ratified Convention No. 169 in 1996 (ILO, 2013; Thomsen, 2013), mandating all decisions of the Danish Government pertaining to Greenland to require free, prior, and informed consent (FPIC) up to when selfrule was instituted in Greenland in 2009 (Hubbard, 2013). Since then, with Indigenous majority rule, the requirement to apply FPIC is contestable. The Greenland affiliate of the Inuit Indigenous peoples organization, the Inuit Circumpolar Council (ICC), still advocates continued use of FPIC in Greenland. However, interviews conducted by Hansen et al. (2016a) revealed that government officials in Greenland considered this request "strange" since FPIC was considered relevant only in decision-making contexts where minorities (or in this case, Indigenous groups) were under-represented. In Greenland, people identifying as Inuit are the majority, making up nearly $90 \%$ of the population (Bjerregaard et al., 2004). Government officials further remarked that they believed that Inuit values are inherently included in the decision-making process for project development since the Inuit are now represented in the Greenland government and have achieved a high degree of independence from Denmark under the Act on Greenland Self-Government (Act no. 473 of 12 June 2009) of the Danish parliament. It is important that the ICC and the government agree in principle on the desired outcomes of public participation in the development process even if they appear to differ in the need for FPIC as a foundation. The differing opinions of the Greenland government and ICC on the role of FPIC therefore call for a discussion about their interpretations of what FPIC entails and what it brings to the development discussion. This discussion could potentially lead to adjustments of the existing system so that the FPIC-related interests promoted by ICC may be secured in the process.

Further, the ICC argues that Inuit in Greenland are represented on the United Nations Permanent Forum on Indigenous Issues and therefore are subject to the rights and entitlements of the UN Declaration on the Rights of Indigenous Peoples. The ICC is of the view that Inuit values are not adequately taken into consideration, especially in relation to industrial development. Therefore, before companies were allowed to bid on new available oil blocks in Nordlandet, the ICC initiated a public debate and facilitated meetings to ensure that their values and concerns were addressed. Ababsi Lyberth (pers. comm. 2013) from the ICC stated: "We are arranging a debate in Nordlandet about areas not yet open for bidding. About if we want it to be used for extraction. We need this type of discussions prior to the political decision-making." He further stressed that "It is important to improve the civil society's possibilities and capacity to enter a dialogue regarding extractive industries before decisions are made."

\section{A Need for Sharing and Transferring Knowledge}

Given the likeliness of future extractive industry development, the ability of local Greenland communities to engage in impact assessment and influence decision making is critical to preserving their way of life. Guidance on how to conduct good impact assessments and engage with local communities exists (McCool and Guthrie, 2001; Bryson et al., 2013; ICMM, 2015). However, to our knowledge, none of the current guidelines specifically target the citizens in affected Arctic communities that aim 
to prepare them for the necessary dialogue about project assessment, development, and community impacts; build the capacity needed for initial and sustained community engagement; and empower and motivate them to do so. In a time and place where public participation fatigue may be problematic, local-to-local recommendations may offer another perspective and provide a better base for engagement in impact assessment processes (and hence more constructive planning processes) for oil and gas projects and extractive activities more generally.

\section{FACTORS CONTRIBUTING TO SUCCESSFUL COMMUNITY ENGAGEMENT}

Studies have found that rapid growth related to hydrocarbon development appears to create cradles of social disruption in so-called "boom-towns," not only in the Arctic but worldwide. Examples of social impacts associated with intensive energy development include lower density of acquaintanceship and a reduced sense of identity and solidarity (Smith et al., 2001). These changes are linked to other social impacts, such as less perceived control of deviant behavior, reduced respect for law and order, less effective socialization of youth, increased drug and alcohol use, and lower overall satisfaction with the community. Perceptions of lacking control over management of natural resources such as minerals, oil, and gas have also been found to greatly influence the degree of community well-being in the Arctic (see e.g., Poppel, 2015). Contrary to some people's expectations, increased employment opportunities have not been found to support the ability of the community to retain its youth, which is generally a primary benefit of economic development (Park and Sokowsky, 2009). These social impacts on communities typically begin before large increases in population from immigration by employment seekers.

A study by Brown et al. (2003) of the Intermountain Power Project, a large, coal-fired generating station in Delta, Utah, developed during the 1980 s, provides a particularly in-depth assessment on how to achieve positive mitigation efforts implemented in conjunction with a major utility project. The study attributes the project's success to a number of factors, including the developer's implementation of impact mitigation, which enabled the community to upgrade infrastructure and provided benefits based on other desired community enhancements. Other factors contributing to the project's perceived success were that funding for community improvements began prior to most of the influx of new residents associated with the project, and that local governments were given access to the decision-making process for the allocation of funds. These findings indicate that it is essential to include community members in the decision-making processes in the early stages of new hydrocarbon projects to secure local benefits and to minimize costs both for the community and for the companies. Kruse (2010) recommends more informed and active involvement of communities that may be subject to impacts from hydrocarbon development, arguing that such involvement can enhance local benefits and lead to more sustainable and lasting solutions.

\section{Traditional Knowledge in Impact Assessment}

Community engagement and incorporation of the traditional knowledge of Indigenous communities are generally considered cornerstones of impact assessment in the Arctic (Noble and Udofia, 2015). Successful participation implies, among other things, that those communities potentially affected by development have the right to participate in project planning and impact assessment prior to implementation of new projects. Another key element of meaningful engagement is a willingness of the proponents and authorities to consider local concerns and values and allow those potentially affected to influence decision making on the basis of their knowledge and values (Noble and Udofia, 2015). This important component of project development assessment agrees with the United Nations Declaration on the Rights of Indigenous Peoples (UNDRIP), which may be considered as the "the most recent and fullest expression of Indigenous peoples' aspirations" (ILO, 2013:10). The principle of FPIC was formally outlined in the 1989 Convention concerning Indigenous and Tribal Peoples in Independent Countries (No. 169) of the International Labour Organization (ILO, 2013). The idea of FPIC was reinforced by UNDRIP (United Nations, 2007), which came into force on 13 September 2007 following adoption of Resolution 61/295 by the UN General Assembly. UNDRIP is composed of an Annex and 46 articles to address the rights of Indigenous people. The principle of Indigenous Peoples' right to free, prior, and informed consent has since been recognized, to varying degrees, by a number of intergovernmental organizations, international bodies, conventions, and international human rights law (Hanna and Vanclay, 2013; MacInnes et al., 2017).

Securing a successful engagement process benefits not only the communities involved, but also the proponents, because when local values and traditional knowledge of locals are not sufficiently integrated into impact assessments in the Arctic, the outcome is often detrimental for project proponents (Hansen et al., 2016a). A series of failed impact assessment applications for mineral exploration took place in the upper Thelon Basin, Northwest Territories, Canada (Ehrlich, 2010). The proponents argued that their projects would have negligible to even positive sociocultural effects on local Indigenous communities; however, the communities disagreed, arguing that the cultural and spiritual values of the land were not adequately considered by the project developers. Ultimately, the project applications were rejected.

Meaningful community engagement means not only providing opportunities for residents affected by development to become engaged, but also ensuring that 
they have the capacity to do so. In a recent review, Noble and Hanna (2015) identified the growing requirements for consultation with Arctic communities, which, combined with increasing numbers of project applications, have generated concerns about the capacity of Arctic communities to engage meaningfully in impact assessment. Further, they suggest that many Indigenous communities lack the financial and human capacity to become and remain engaged, in part because of the very large, complex, and technical nature of the assessments being conducted. Road to Improvement: A review of regulatory systems across the North (McCrank, 2008) identified similar concerns about the capacity of Indigenous communities to document traditional knowledge to assist in impact assessment. The Alaska Forum on the Environment identified the concern that communities not only need to see the benefits of their engagement in impact assessment, but also require the resources to participate (IWG, 2011). Unfortunately, the problem is not new: Huttunen (1999), reporting on experiences in northern Finland, noted that community engagement in the Sierilä hydropower assessment contributed to their realization of the need for local empowerment and self-management, and cautioned that many communities often lack the capacity to participate.

\section{CASE STUDY: THE NORTH SLOPE OF ALASKA}

\section{Study Area and Data Collection}

This case study is part of a larger research project on the impacts of oil and gas in Alaska, undertaken as a part of Hansen's Fulbright Arctic Initiative award (see Virginia et al., 2016). The choice of the North Slope of Alaska as a case study was based on the common features this area shares with Greenland: both areas are characterized by small, rural coastal settlements subject to oil and gas activities, and Inuit are the majority in all these communities. The regions differ in their colonial histories and in their political, legal, and regulatory systems; however, despite these differences, we believe there are lessons to be learned that can serve as inspiration and guidance for Greenland communities.

During data collection for the Fulbright project, key issues emerged as important lessons learned by local residents in Alaska in relation to industry development, and these issues became the focus of this paper. They were identified by local interviewees, as recommendations for Greenlandic communities planning for oil development.

The case study was conducted in the spring of 2016 using research methods described in Bernard (1988). Field note observations were collected and interviews conducted by Hansen in the Alaskan cities of Fairbanks and Anchorage and in the North Slope villages of Utqiagivik, Deadhorse, and Nuiqsut. Field notes include minutes from conversations with more than 80 people in North Slope Borough (NSB) communities, including young, middle-aged, and elder men and women from different families and a wide variety of occupations. The conversations were about life in Alaska in general and about hydrocarbon development in particular.

Semi-structured interviews with selected stakeholders supplemented the field notes. A total of 26 interviews were conducted during face-to-face meetings with respondents chosen for their expertise and insights into NSB development, including hydrocarbon development. Efforts were made to ensure that the interview pool encompassed a range of interests and opinions from business, government, research, and Inuit and non-Native communities. Specifically, the interviews included seven experts engaged in oil and gas research on the North Slope, six local governmental (NSB) officials, five nonNative residents of Utqiagivik, two native residents of Utqiagivik, two workers in Deadhorse and Prudhoe Bay, two Native persons from regional corporations, and two Native persons from village corporations. For analysis purposes, these respondents have been divided into three stakeholder groups: local government officials, North Slope residents, and researchers. Local government officials and some of the researchers were also North Slope residents, but were interviewed with a focus on their occupation and encouraged to share insight from their professional experience rather than their individual or personal experiences.

\section{Case Study Findings and Recommendations}

During the interviews, interviewees shared different recommendations based on their experience as local government representatives, citizens of an affected community, or researchers investigating impacts or working with industry to conduct impact assessments. Each group held distinct perspectives on the development; the main recommendations coming from each interest group are summarized in Table 1.

Local Government Officials: The local NSB government officials whom we interviewed emphasized the importance to Greenlanders of taking independent action by preparing early and not waiting for industry to engage with them. They recommended that, as soon as a community learns of potential development activity, the community should prepare its own land-use plan-also referred to as a "cultural plan"- that identifies hunting areas and important spiritual, camping, and animal sites, and captures stories about the land from the elders before development occurs. Officials explained that creating such a land-use plan will preserve community heritage, as well as provide a baseline for impact assessments and the related consultation processes. They also emphasized the importance and value of updating a community's landuse plan as warranted during the development, monitoring any impacts, and following up on mitigation programs, as necessary.

Another recommendation put forward by the government officials was that community members 
TABLE 1. Overview of recommendations from Alaskans to Greenlanders.

Local government officials:

Make your own land-use plan.

Negotiate benefit agreements that secure jobs for local residents not primarily in industry, but in the supply chain.

Get the companies to invest in and develop local businesses instead of training people to work in industry.

Push your governments to develop health and infrastructure services.

Prepare your communities by identifying local people to train in regulations, participate in meetings, and report back to the community (ambassadors).

Local people:

Invite government officials and politicians to meet with you in your community to talk before the companies come.

Advocate for allocation of government funds to secure development of good community infrastructure and housing.

Strive to secure equal rights for all people in the community.

Develop organized collaborative entities with other affected communities.

Researchers:

Look into how to support so-called "super households" to support the whole community.

Find ways to make it attractive for women and families to remain in the community, increasing collective security.

Acknowledge that many community members do not perceive industry as a future solution and strive to protect the potential

for living and thriving in the community without taking part in the industry.

should not pursue jobs only (or primarily) in industry, as these opportunities may be temporary. They found that to build local capacity and support sustainable development in communities, financial resources are better spent by investing in local businesses that are owned and driven by community members, or service jobs to be held by hunters to combine paid work and subsistence hunting, rather than on training people to work solely in industry. Heavy dependency on oil jobs, they found, creates anxiety for the future, while promotion of development in other sectors of the economy will lead to less stress in the community and more sustainable solutions in the long run.

The NSB government officials also suggested that Greenlanders should be aware of the increased need for health and infrastructure services when industry initiates project development, prepare for growth in the area, and be able to monitor and report changes in community well-being resulting from increased development. Such investments help communities to prepare for a range of issues and to incorporate and implement mitigation measures should unexpected impacts occur.

Finally, the government officials recommended that Greenland communities prepare to take part in decisionmaking processes early, for example, by educating representatives in the communities about how new laws might affects their lives and preparing them to take part in and influence project development through education about the rules and regulatory systems in place.

North Slope Residents: The citizens whom we interviewed in the villages emphasized the need to secure good infrastructure and housing opportunities for residents in the affected communities. Many interviewees had experienced family members, relatives, friends and others moving into the community when hydrocarbons were developed in their area. This influx of new residents often creates a housing shortage. When industry expands into an area, housing is usually created for the company so that migrant workers can have immediate shelter without affecting the local housing stock. However, the local citizens whom we interviewed stated that the company housing was not sufficient. They explained that the communities ultimately experience a population increase from more births and the migration of Alaskans and other Americans from the south to start up service businesses (e.g., restaurants, hotels, retail) in conjunction with industrial development. On the basis of these experiences, the local citizens suggested that Greenland communities faced with industry development should push for government funding to secure development of proper infrastructure and housing in anticipation of the social pressures mentioned above.

Another issue highlighted by the NSB residents was the experience of unfair treatment or discrimination against local community members. They explained that perceived discrimination had caused internal disputes in communities. Examples mentioned included children of corporate board members being offered better positions and better salaries than people who had no strong ties to industry and the sexual harassment of women working in the industry. The interviewees recommended that Greenlanders strive for equal rights for all people to avoid discrimination and internal disputes in the community when industry is settling.

Finally, a recommendation brought forward on several occasions was for Greenlanders to develop organized collaborative entities. The Alaskans would refer to the Alaska Eskimo Whaling Commission (AEWC) as a good example of how communities can work together to protect common interests and represent the people in an empowered manner in decision-making processes around industry.

Researchers: The researchers interviewed suggested that Greenlanders should look into how development could support so-called "super households" to promote community well-being and food security (Magdanz and Utermohle, 1998; Wolfe et al., 2009). Sharing in Alaskan communities occurs primarily between extended families. Each such family encompasses multiple households and often three to four generations of kin linked by traditional social organizational ties, as well as the families of hunting crew members. Several "super households," about $20 \%-30 \%$ of those in the community, account for approximately $70 \%$ of the total harvest production 
and constitute the center of subsistence production and distribution.

This recommendation to encourage and support super households was based on both the research findings and the researcher's personal experiences working closely with Alaskan communities. An example mentioned was providing more support to whaling captains to fund boats and hunting gear, rather than spreading these funds equally among individuals. Early impressions indicate that this approach is a more culturally appropriate and effective way to support Inuit communities and creates less disruption than, for example, the dividend cheque system used in Alaska (see Dayo and Kofinas, 2009).

Researchers mentioned as problematic to development the commonly held view that women are more likely to become educated and leave the villages while the men stay behind. It was therefore suggested that Greenlanders consider what would make it attractive for women to stay and have families in the communities. Creating better job opportunities for women would make them more able to financially support a household and contribute to more equal economic partnerships, which might lead to less domestic violence and more stable families.

The researchers also suggested that communities make it clear to local governments, industry, and EIA professionals that industry is not perceived as a future solution or a lifestyle alternative to the subsistence hunting livelihood valued in many communities. They emphasized that they have experienced how people have become dependent on oil money even if they are not working in the industry themselves because of the way the money is managed, which makes them vulnerable when the resource is exhausted. Such outcomes call for better planning and more consideration of how to secure local benefits in the long run, and the researchers therefore suggested that Greenlanders should be aiming for long-term solutions during investments related to industry.

\section{A COMMUNITY GUIDE FOR SUCCESSFUL COMMUNITY ENGAGEMENT}

Community members in Greenland report they lack information and guidance on how to engage and influence decision making on questions related to hydrocarbon development, which can bring significant changes to their lives. Communities in Alaska are experienced and open to sharing recommendations, and our study indicates that such experience, expertise, and knowledge would prove valuable to Greenland communities charting their future.

There are also other Arctic experiences and case studies to draw upon. They span important differences in the country-specific context for impact assessment and community-based participation in decision making. Central to this decision making process is full consideration of the cultural translation when moving information from one Arctic setting to another. We expect that sharing experiences across the Arctic region will lead to better development outcomes. A more formally framed process with more actors from different sectors should lead to even better input and guidance for local communities on their place-based options to achieve a sustainable development future.

We propose that preparation of a guideline could for example include the following practical steps:

- Collect data from Arctic communities subject to hydrocarbon development: Analyze statistical and demographic background, summarize existing knowledge, and examine case studies in selected communities (include success cases).

- Bring Northerners together across disciplines in workshops and through social media to discuss the structure and potential content of a guide based on the gathered experiences: Identify potential recommendations, seek public comment, and create a framework for updating the process.

- Conduct follow-up studies, focusing on the issues identified during the workshops, to map how the recommendations have been met in different cases and how the results have influenced local perceptions of success.

- Publish guidelines and distribute them widely and create a forum for continuing dialogue through social media and the web.

- Develop a process to update and re-evaluate the guidelines as more experiences are gathered and as industry practices change and evolve.

We see a community guide as a potentially central tool for promoting community well-being and supporting good management of extractive projects. In principle, this would be an accessible document prepared by and written for communities to help them evaluate the opportunities and consequences of extractive industry development. The general outline presented above suggests a process for moving ahead, bringing Alaskan and Greenland community members together to share their experiences and expectations with the process of oil exploration and development. It is critical that resources be found to support this community dialogue and translate the outcomes into a practical and updateable community guide. This guide will not replace more technical planning documents and assessments, but it will increase community engagement in the development process and cooperation among stakeholders and reduce community stress over addressing complex development issues.

\section{ACKNOWLEDGEMENTS}

This work has been supported by a Fulbright grant through the U.S. Department of State Fulbright Arctic Initiative. The content does not represent an endorsement or approval by 
the Government of the United States or any representative agency. We thank people in Fairbanks, Anchorage, Utqiagivik, Deadhorse, and Nuiqsut, for their contributions.

\section{REFERENCES}

AMAP (Arctic Monitoring and Assessment Programme). 2007. Arctic oil and gas 2007. Oslo, Norway: AMAP. 40 p. https://www.amap.no/documents/doc/arctic-oil-andgas-2007/71

Anderson, B.J., and Theodori, G.L. 2009. Local leaders' perceptions of energy development in the Barnett Shale. Southern Rural Sociology 24(1):113-129.

http:/journalofruralsocialsciences.org/pages/Articles/ SRS\%202009\%2024/1/SRS\%202009\%2024\%201\%20113129.pdf

Bernard, H.R. 1988. Research methods in cultural anthropology. Thousand Oaks, California: Sage Publications.

Bjerregaard, P., Young, T.K., Dewailly, E., and Ebbesson, S.O.E. 2004. Indigenous health in the Arctic: An overview of the circumpolar Inuit population. Scandinavian Journal of Public Health 32(5):390-395. https://doi.org/10.1080/14034940410028398

Brown, R.B., Clay, M., Paksima, S., Dorius, S.F., and Rowely, K. 2003. Local flexibility in spending mitigation monies: A case study of successful social impact mitigation of the Intermountain Power Project in Delta, Utah. Impact Assessment and Project Appraisal 21(3):205-213.

https://doi.org/10.3152/147154603781766220

Bryson, J.M., Quick, K.S., Slotterback, C.S., and Crosby, B.C. 2013. Designing public participation processes. Public Administration Review 73(1):23-34. https://doi.org/10.1111/j.1540-6210.2012.02678.x

Dayo, D., and Kofinas, G. 2009. Institutional innovation in less than ideal conditions: Management of commons by an Alaska Native village corporation. International Journal of the Commons 4(1):142-159.

https://doi.org/10.18352/ijc.146

Ehrlich, A. 2010. Cumulative cultural effects and reasonably foreseeable future developments in the Upper Thelon Basin, Canada. Impact Assessment and Project Appraisal 28(4):279-286.

https://doi.org/10.3152/146155110X12838715793084

Glasson, J., Therivel, R., and Chadwick, A. 2013. Introduction to environmental impact assessment. New York: Routledge. https://doi.org/10.1080/07293682.2012.745889

Government of Greenland. 2014. Greenland's oil and mineral strategy 2014-2018.

http://naalakkersuisut.gl/ /media/Nanoq/Files/Publications/ Raastof/ENG/Greenland\%20oil\%20and\%20mineral\%20 strategy\%202014-2018_ENG.pdf

Hanna, P., and Vanclay, F. 2013. Human rights, Indigenous peoples and the concept of free, prior and informed consent. Impact Assessment and Project Appraisal 31(2):146-157.

https://doi.org/10.1080/14615517.2013.780373
Hansen, A.M., and Larsen, S.V. 2016. Miljøvurdering af offshore kulbrinte aktiviteter: En benchmarkingundersøgelse af krav til VVM for efterforskningsaktiviteter i Grønland, Norge, Canada, Danmark og Alaska [Environmental assessment of offshore hydrocarbon activities: A benchmarking study of EIA requirements for exploration activities in Greenland, Norway, Canada, Denmark and Alaska]. Aalborg: Danish Centre for Environmental Assessment, Aalborg University.

Hansen, A.M., and Tejsner, P. 2016. Identifying challenges and opportunities for residents in Upernavik as oil companies are making a first entrance into Baffin Bay. Arctic Anthropology 53(1):84-94.

https://doi.org/10.3368/aa.53.1.84

Hansen, A.M., Adamson, J., Christensen, H.-P.B., Garpestad, E., and Le Breton, H. 2015. Corporate collaboration: Drivers behind a joint industry social baseline study related to hydrocarbon exploration in Greenland. Impact Assessment and Project Appraisal 33(4): 284-289. https://doi.org/10.1080/14615517.2015.1083214

Hansen, A.M., Tejsner, P., and Egede, P. 2016a. Traditional knowledge and industrial development: On the potential use of Indigenous and local knowledge as a resource to assess competencies in Greenland. In: Knudsen, R., ed. Perspectives on skills: An anthology on informally acquired skills in Greenland. Chapter 7.1. Copenhagen, Greenland Perspective, University of Copenhagen. 152-166.

Hansen, A.M., Vanclay, F., Croal, P., and Skjervedal, A.-S.H. 2016b. Managing the social impacts of the rapidly-expanding extractive industries in Greenland. The Extractive Industries and Society 3(1):25-33.

https://doi.org/10.1016/j.exis.2015.11.013

Hubbard, R. 2013. Risk, rights and responsibility: Navigating corporate responsibility and Indigenous rights in Greenlandic extractive industry development. Michigan State International Law Review 22(1):101 - 166.

https://digitalcommons.law.msu.edu/ilr/vol22/iss1/4

Huttunen, A. 1999. The effectiveness of public participation in the environmental impact assessment process - a case study of the projected Sierilä hydropower station at Oikarainen, northern Finland. Acta Borealia 16(2):27-41.

https://doi.org/10.1080/08003839908580496

ICMM (International Council on Mining \& Metals). 2015. Good practice guide: Indigenous peoples and mining, 2nd ed. London: ICMM.

https://www.icmm.com/website/publications/pdfs/social-andeconomic-development/9520.pdf

ILO (International Labour Organization). 2013. Understanding the Indigenous and Tribal Peoples Convention. Convention No. 169 (1989). Geneva: ILO. 57 p.

IWG (Interagency Working Group on Environmental Justice). 2011. Agency responses to comments received during the 2011 Alaska Forum on the Environment. EJ IWG Community Dialogue, 7-11 February 2011, Anchorage, Alaska. Washington, D.C.: U.S. Environmental Protection Agency. http://www.doi.gov/pmb/oepc/upload/alaska-forum-2011agency-responses.pdf 
João, E., Vanclay, F., and den Broeder, L. 2011. Emphasising enhancement in all forms of impact assessment: Introduction to a special issue. Impact Assessment and Project Appraisal 29(3):170-180.

https://doi.org/10.3152/146155111X12959673796326

Kruse, J. 2010. Sustainability from a local point of view: Alaska's North Slope and oil development. In: Winther, G., ed. The political economy of northern regional development, Vol. 1. Copenhagen: Nordic Council of Ministers. 55-72. https://doi.org/10.6027/tn2010-521

MacInnes, A., Colchester, M., and Whitmore, A. 2017. Free, prior and informed consent: How to rectify the devastating consequences of harmful mining for Indigenous peoples'. Perspectives in Ecology and Conservation 15(3):152 - 160. https://doi.org/10.1016/J.PECON.2017.05.007

Magdanz., J., and Utermohle, C.J. 1998. Family groups and subsistence. Cultural Survival Quarterly Magazine, September. https://www.culturalsurvival.org/publications/culturalsurvival-quarterly/family-groups-and-subsistence

McCool, S.F., and Guthrie, K. 2001. Mapping the dimensions of successful public participation in messy natural resources management situations. Society \& Natural Resources 14(4):309-323. https://doi.org/10.1080/713847694

McCrank, N. 2008. Road to improvement: The review of the regulatory systems across the North. Ottawa: Indian and Northern Affairs Canada.

https://slwb.com/sites/default/files/mvlwb/documents/ McCrank-Report.pdf

Morgan, R.K. 2012. Environmental impact assessment: The state of the art. Impact Assessment and Project Appraisal 30(1):5-14.

https://doi.org/10.1080/14615517.2012.661557

Naalakkersuisut (Government of Greenland). 2016. Social impact assessment (SIA): Guidelines on the process and preparation of the SIA report for mineral projects. Nuuk: Ministry of Industry, Labor and Trade, Government of Greenland. https://www.govmin.gl/images/Documents/Socio_ Economics/SIA_guideline.pdf

2018. Mineral occurrences: Mineralizing environments and related mineral occurrences throughout Greenland's geological history.

https://www.govmin.gl/en/minerals/mineral-occurrences

Noble, B.F., and Hanna, K. 2015. Environmental assessment in the Arctic: A gap analysis and research agenda. Arctic 68(3):341-355. https://doi.org/10.14430/arctic4501

Noble, B.F., and Udofia A. 2015. Protectors of the land: Toward an EA process that works for Aboriginal communities and developers. Ottawa, Ontario: MacDonald-Laurier Institute. https://www.macdonaldlaurier.ca/files/pdf/Noble-EAs-Final. pdf

Olsen, A.-S.H., and Hansen, A.M. 2014. Perceptions of public participation in impact assessment: A study of offshore oil exploration in Greenland. Impact Assessment and Project Appraisal 32(1):72-80.

https://doi.org/10.1080/14615517.2013.872842
Park, M., and Stokowski, P.A. 2009. Social disruption theory and crime in rural communities: Comparisons across three levels of tourism growth. Tourism Management 30(6):905-915. https://doi.org/10.1016/j.tourman.2008.11.015

Pearce, R. 1994. The internationalisation of research and development by multinational enterprises and the transfer sciences. Empirica 21(3):297-311. https://doi.org/10.1007/BF01697411

Poppel, B. 2015. Living conditions and perceived quality of life among Indigenous Peoples in the Arctic. In: Glatzer, W., Camfield, L., Møller, V., and Rojas, M., eds. Global handbook of quality of life: Exploration of well-being of nations and continents. Dordrecht: Springer Netherlands. 715-743. https://doi.org/10.1007/978-94-017-9178-6_32

Robertson, J., Pierce, B., and Gautier, D. 2008. 90 billion barrels of oil and 1,670 trillion cubic feet of natural gas assessed in the Arctic. Podcast, July 22. Washington, D.C.: U.S. Geological Survey.

https://www.usgs.gov/media/audio/90-billion-barrels-oil-and1670-trillion-cubic-feet-natural-gas-assessed-arctic

Senécal, P., Goldsmith, B., Conover, S., Sadler, B., and Brown, K. 1999. Principles of environmental impact assessment best practice. Fargo, North Dakota: International Association for Impact Assessment. https://www.iaia.org/uploads/pdf/principlesEA_1.pdf

Smith, M.D., Krannich, R.S., and Hunter, L.M. 2001. Growth, decline, stability, and disruption: A longitudinal analysis of social well-being in four western rural communities. Rural Sociology 66(3):425-450. https://doi.org/10.1111/j.1549-0831.2001.tb00075.x

Stedman, R.C., Jacquet, J.B., Filteau, M.R., Willits, F.K., Brasier, K.J., and McLaughlin, D.K. 2012. Environmental reviews and case studies: Marcellus shale gas development and new boomtown research: Views of New York and Pennsylvania residents. Environmental Practice 14(4):382 - 393.

https://doi.org/10.1017/S1466046612000403

Thomsen, M.L. 2013. Greenland and the United Nations declaration on the rights of Indigenous Peoples. In: Loukacheva, N., ed. Polar law textbook II. Copenhagen: Nordic Council of Ministers. 241-267.

United Nations. 2007. Declaration on the rights of Indigenous people. Resolution 61/295 adopted by the General Assembly, 107th Plenary Meeting, September 13.

http://www.un.org/esa/socdev/unpfii/documents/DRIPS en.pdf

Vanclay, F., Esteves, A.M., Aucamp, I., and Franks, D.M. 2015. Social impact assessment: Guidance for accessing and managing the social impacts of projects. Fargo, North Dakota: International Association for Impact Assessment. https://www.iaia.org/uploads/pdf/SIA_Guidance_Document_ IAIA.pdf

Virginia, R.A., Sfraga, M., Arnbom, T., Chamberlain, L., Chatwood, S., Dis, A.T., Gjørv, G.H., et al. 2016. Fulbright Arctic Initiative: An innovative model for policy relevant research and public outreach. Arctic Yearbook 2016:180-193. https://www.arcticyearbook.com/images/Articles_2016/ briefing-notes/5-AY2016-Virginia.pdf 
Wilson, E., Hansen, A.M., and Rowe, E.W. 2017. Imagining the future: Local perceptions of Arctic extractive projects that didn't happen. In: Kelman, I., ed. Arcticness: Power and voice from the North. London: UCL Press. 130-149. https://doi.org/10.14324/111.9781787350137

Wolfe, R.J., Scott, C.L., Simeone, W.E., Utermohle, C.J., and Pete, M. 2009. The "super-household" in Alaska Native subsistence economies: A report to the National Science Foundation, ARC 0352611. San Marcos, California: Robert J. Wolfe and Associates.
Wood, C. 2003. Environmental impact assessment: A comparative review, 2nd ed. New York: Pearson/Prentice Hall.

World Economic Forum. 2016. What's behind the drop in oil prices? March 2.

https://www.weforum.org/agenda/2016/03/what-s-behind-thedrop-in-oil-prices/ 